JURNAL GEOGRAFI

Geografi dan Pengajarannya

ISSN 1412 - 6982

e-ISSN : 2443-3977

Volume XVIII Nomor 1 Juni 2020

\title{
ANALISIS DAMPAK RELOKASI PEMBANGUNAN WILAYAH PASAR TRADISIONAL SONGGOLANGIT KABUPATEN PONOROGO TAHUN 2020
}

\author{
Ardhyan Dwi Nurcahyo \\ SMA N 2 Ponorogo
}

Jl. Pacar No.24, Tonatan,, Ponorogo, Jawa Timur, 63418

Program Magister Pendidikan Geografi, Sekolah Pascasarjana, UNESA, Jl. Lidah Wetan, Lakarsantri, Surabaya, Jawa Timur 60213

\begin{abstract}
Abstrak: Pasar tradisional Songgolangit memiliki peranan penting dalam perdagangan di kabupaten Ponorogo. Dalam setiap pembangunan memiliki rencana revitalisasi atau pembaharuan untuk menunjang kenyamanan dalam jual-beli. Dampak dari Revitalisasi adalah relokasi sementara pedangang Pasar Tradisional Songgolagit. Pemilihan tempat relokasi Pasar Songgolangit perlu ditentukan dengan cermat. lokasi pasar menjadi peranan penting dalam percepatan pertumbuhan sector ekonomi suatu daerah. Berdasarkan deskripsi tersebut teori lokasi merupakan teori dasar dalam membuat analisis spasial yang didalamnya terdapat tata ruang dan penentuan lokasi kegiatan ekonomi menajdi hal utama. Oleh sebab itu diperlukan analisis menganai kesesuaian pemilihan teori berdasarkan teori August Losch dan analisis Dampak sosial ekonomi masyarakat sekitar pasar relokasi dan pedagang pasar Songgolangit. Jenis penelitian yang digunakan kualitatif dengan menggunakan teknik analisis deskriptif. Hasil penelitian menunjukan kesesuaian pemilihan lokasi relokasi berdasarkan teori August Losch karena mengutamakan faktor permintaan konsumen dan masih termasuk pada kawasan perkotaan. Dampak analisis sosial-ekonomi dari relokasi menunjukan kecondongan dampak positif terhdap relokasi meskipun terdapat dampak negatif.
\end{abstract}

Kata kunci : Pasar Songgolangit, Relokasi, Revitalisasi

\section{A. PENDAHULUAN}

Pasar tradisional dapat dijadikan sebagai satu variabel pembentukan (formasi) kelas dalam masyarakat. Hal ini terjadi karena pasar dapat memberikan identitas sosial. Dalam konteks ini, pasar tradisional tidak hanya dapat dilihat sebagai suatu tempat (space) bagi transaksi ekonomi tetapi juga sebagai tempat berlangsungnya proses sosial lainnya. Hal ini terjadi karena kegiatan ekonomi (pasar) merupakan kegiatan yang tak terpisahkan dari masyarakat. Pasar bukan hanya dipahami sebagai ruang ekonomi, tetapi sebagai ruang sosial, ruang budaya dan juga ruang politik. Fenomena tersebut menunjukkan bahwa fenomena pasar bukanlah fenomena yang sederhana tetapi merupakan fenomena yang kompleks.

Pasar tradisional merupakan tempat terjadinya transaksi jual beli antara produsen dengan konsumen, dan merupakan salah satu sumber penggerak perekonomian. Pengelolaan pasar di Indonesia umumnya dilakukan oleh Perusahaan Daerah Pasar dan 
kepemilikan kios/toko secara perorangan. Berdasarkan sifat kegiatan dan jenis dagangannya (termasuk pasar lelang), pasar tradisional dibedakan menjadi pasar eceran, pasar grosir, pasar induk dan pasar khusus. Sedangkan dilihat dari ruang lingkup pelayanan dan tingkat potensi pasar, dikenal keberadaan pasar lingkungan, pasar wilayah, pasar kota, dan pasar regional, dengan waktu kegiatan pasar siang hari, pasar malam hari, pasar siang malam dan pasar kaget/pekan (Mahendra, 2004).

Dalam proses pembangunan pasar sebagai pusat pembelanjaan, dapat dilakukan dengan melakukan beberapa penilaian terhadap pasar (market) agar target pasarnya tepat dan dapat menentukan konsep pusat pembelanjaan yang akan dibangun nantinya. Analisis itu seperti, analisis tapak yang berguna untuk menilai kelayakan dari tapak, seperti lokasi, aksesibilitas, lingkungan sekitar, dan rencana kota. Disamping analisis tapak, perlu diperhatikan kondisi demografi dan ekonomi, seperti jumlah penduduk dan trend pertumbuhannya, pendapatan atau pengeluaran perkapita. Analisis makro untuk overview pasar sebagai pusat pembelanjaan, yang melihat skala makro pasar pusat pembelanjaan yang tersebar di area dekat lokasi pembangunan pusat pembelanjaan baru, yang bisa dilihat dari segi pasokan, permintaan, trend harga, periode kontrak sewa dan cara pembayaran, serta prospek.

Pemilihan lokasi memiliki peranan penting dalam percepatan pertumbuhan ekonomi suatu daerah, demikian juga dengan lokasi pasar sebagai pusat pembelanjaan bagi masyarakat. Dengan demikian teori lokasi merupakan teori dasar dalam analisis spasial dimana tata ruang dan lokasi kegiatan ekonomi merupakan unsur utama. Teori lokasi ini memberikan kerangka analisis yang baik dan sistematis mengenai pemilihan lokasi kegiatan ekonomi (dalam hal ini adalah lokasi pasar tradisional sebagai pusat pembelanjaan). Salah satu teori lokasi yang ada adalah teori lokasi yang dikembangkan oleh August Losch (1954), yang mempelopori Teori Lokasi Market Area dan mendasarkan analisis pemilihan lokasi optimal pada luas pasar yang dapat dikuasai dan kompetisi antar tempat. Artikel ini menekankan pada Teori Lokasi Market Area, yang mendasarkan pandangan bahwa produsen akan memilih tempat sebagai lokasi yang optimal berdasarkan kekuatan persaingan antar tempat dan luas pasar yang dapat dikuasainya.

Teori Lokasi Market Area dapat digunakan sebagai salah satu pedoman 
dalam penetapan lokasi pembangunan pasar tradisional (pasar pembantu) dalam suatu perkotaan. Penerapan konsep dan model yang berbeda oleh beberapa ahli tentang lokasi pembangunan pasar tradisional digambarkan dan dianalisis melalui studi literatur, sehingga dapat ditemukan hasil yang sesuai dengan harapan dan tercapainya tujuan penulisan artikel ini.

Proses Relokasi Pasar Songgolangit akibat dari Program Revitasisasi. Pasar Tradisional harus mempertimbangan pemilihan tempat yang strategis agar pemintaan terhadap Pasar Songgolangit tidak menurun sehingga tidak merugikan para pedangang dan masyarakat sekitar serta menjadikan ekonomi tumbuh. Tidak hanya itu dalam proses relokasi pasar juga perlu dilakukan analisis dampak sosial-ekonomi terhadap para pedagang dan masyarakat sekitar pasar sementara di Jl. Cipto Mangunkusumo sehingga dapat diketahui dampak yang ditimbulkan dari proses relokasi pasar sementara ini. Alasan lain pemilihan relokasi pasar Songgolangit karena merupakan pasar terbesar di Ponorogo dan memiliki perputaran uang yang besar.

Peneliti mengambil rumusan masalah (1) bagaimana kesesuaian pemilihan lokasi Relokasi Pasar Songgolangit dengan Teori Lokasi August Losch, (2) bagaimana dampak sosial-ekonomi Relokasi Pasar Songgolangit terhadap masyarakat dan pedagang.

Berdasarkan latar belakang di atas maka penulis melakukan penelitian dengan judul "analisis dampak relokasi pembangunan wilayah pasar tradisional songgolangit kabupaten ponorogo tahun 2020" dengan tujuan untuk mengetahui kesesuaian pemilihan lokasi relokasi Pasar Songgolangit dengan Teori August Losch dan untuk mengetahui dampak sosial-ekonomi relokasi Pasar Songgolangit terhadap pedagang dan masyarakat.

\section{B. METODE PENELTIAN}

Jenis penelitian yang digunakan dalam penelitian ini adalah penelitian deskriptif dengan pendekatan kualitatif. Lokasi penelitiaan di relokasi Pasar Tradisional Songgolangit dan di pasar sementara Jl. Cipto Mangunkusumo, Ponorogo. Teknik pengumpulan data yang digunakan adalah observasi dan wawancara. Teknik analsis data adalah analisis deskiptif. 
C. Hasil dan Pembahasan

1. Peta Multi Temporal

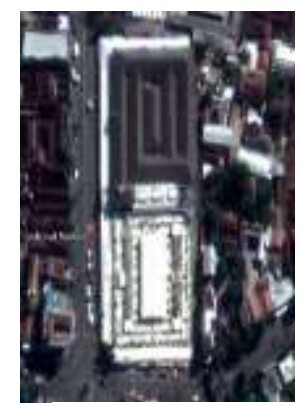

Gambar 1

Pasar Lama

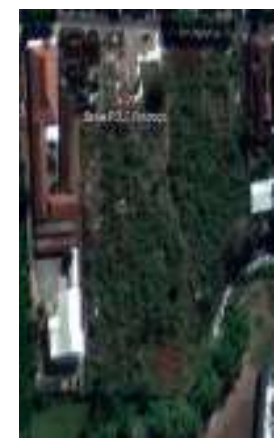

Gambar 3 I okasi harı

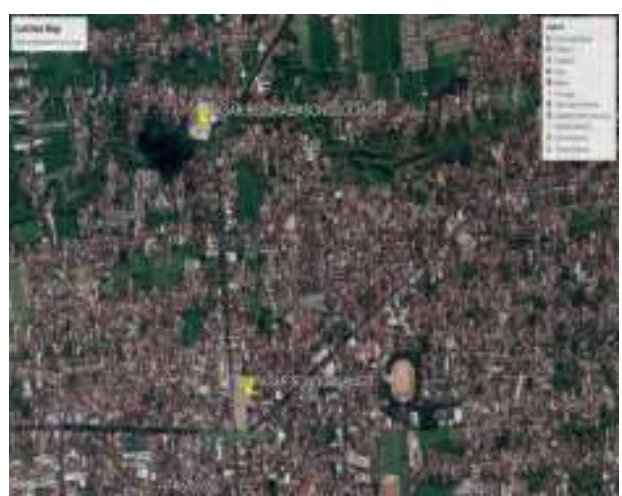

Gambar 5. Lokasi Ke 2 Pasar

2. Analisis pembangunan wilayah berdasarkan Teori lokasi August Losch

Peta temporal pada Gambar menunjukkan bahwa lokasi pasar berada di dekat pemukiman. Hal ini sesuai dengan teori Market Area Losch yang memusatkan perhatian pada permintaan pasar Losch menekankan bahwa lokasi penjual sangatlah berpengaruh terhadap konsumen yang digarapnya. Seorang konsumen tidak mungkin akan membeli barang dengan jarak ke penjual $8 \mathrm{~km}$ karena ada penjual barang yang sama dengan jarak $1 \mathrm{~km}$, mereka akan memilih yang lebih dekat karena lebih efisien dalam kegiatan ekonomi. Makin jauh dari pasar, konsumen makin enggan membeli karena biaya transportasi untuk mendatangi tenpat penjualan (pasar) semakin mahal.

Berdasarkan definisi teori lokasi Losch yang menetapkan lokasi berdasarkan pemintaan pasar. Hal ini sesuai dengan karakteristik pemilihan pasaar yang baru karena: (a) Konsumen tersebar merata antar tempat, artinya teori ini cocok diberlakukan di daerah perkotaan dimana konsentrasi penduduk dan industri relative merata dibandingkan dengan daerah perdesaan atau pedalaman. (b) Produk homogen, sehingga persaingan sangat ditentukan oleh harga dan ongkos angkut. (c) Ongkos angkut per satuan jarak (ton/km) adalah sama (No Economies of Long Haul). (d) Konsumen bersifat rasional, yaitu melakukan pembelian pada lokasi pasar yang dekat dengan tempat tinggal. (Sjarfizal : 2008). Hal ini sesuai dengan 
teori Losch bahwa penentuan lokasi pasar berada pada daerah perkotaan yang memiliki pemintaan yang besar dibandingkan daerah pinggiran kita/ pedesaan..

Fungsi pasar akan berperan optimal untuk memenuhi kebutuhan masyarakat sekitar pasar pembantu. Bahan baku dan pasokan barang setengah jadi dibawa dari berbagai lokasi yang jaraknya tidak bisa ditentukan. Biaya transportasi yang dikeluarkan oleh produsen untuk mengangkut barang ke lokasi pasar bisa ditekan dengan membawa barang dalam jumlah besar. Disamping itu ongkos angkut per kesatuan jarak (ton/km) adalah tidaklah sama. Misalnya, ada dua buah usaha dalam sebuah pasar, yaitu A dan B. Usaha A memperoleh barang jadi dari daerah $\mathrm{C}$ tidak akan sama dengan usaha B yang memperoleh barang dari daerah D. Disini faktor jarak sangat menentukan, akibatnya harga barang yang ditawarkan ke konsumen akan berbeda. Apabila pasar yang dimasuki adalah pasar persaingan sempurna, maka untuk menekan biaya transportasi tersebut dilakukan dengan memesan barang dalam skala besar, sehingga bisa menghemat biaya angkut ke lokasi pasar. Dengan demikian, harga yang ditawarkan pada konsumen pun akan bersaing.

\section{Analisis sosial dan ekonomi masyarakat dan pedagang di lokasi relokasi}

\section{a. Dampak Sosial}

Dampak sosial yang terjadi di Pasar sementara Jl. Cipto Mangunkusumo dialami oleh pedagang dan pekerja serta masyarakat sekitar. Terkait dengan dampak sosial yang menunjukkan perubahan langganan yaitu bergantinya pembeli tetap (langganan) yang biasa membeli di satu pedagang tetapi setelah relokasi, menjadi pembeli langganan pedagang lain. Dari hasil study literatur Nisa'Un (2019) peneliti mendapatkan data yang menyatakan tidak ada perubahan pembeli yang signifikan atau memiliki pengaruh besar bagi pedagang setelah pasar direlokasi. Walaupun ada beberapa pedagang yang merasakan dampak perubahan pelanggan yaitu penurunan pelanggan, dampak ini hanya terjadi pada sebagian kecil pedagang yang menurut pandangan peneliti adalah karena faktor tempat atau kios berjualan pedagang tersebut terletak di bagian paling belakang pasar Jl. Cipto Mangunkusumo sehingga kurang strategis.

Hasil study literatur Nisa'Un (2019) oleh peneliti tidak menunjukkan adanya dampak kemacetan yang meresahkan karena ada 2 titik keluar dan masuknya kendaraan di Pasar Jl. Cipto 
Mangunkusumo. Selain itu juga disediakan 2 orang petugas parkir untuk mengatur lalu lintas kendaraan yang keluar dan masuk pasar. Kepadatan kendaraan meningkat dan menjadikan kondisi jalan lebih padat tetapi tidak macet dan dalam batas kelancaran yang normal. Kepadatan lalu lintas hanya saat pagi hari yang meliputi jam 6.00-6.45 pagi dimana banyak pengguna kendaraan (pelajar, pekerja, dan orang umum termasuk pembeli yang menuju Pasar Jl. Cipto Mangunkusumo) yang melewati jalan dan pada saat sore hari volume kendaraan juga meningkat karena jadwal pulang pekerja dan pelajar pada jam 16.00-17.00 sore.

Dampak sosial yang terjadi adalah pengelolaan sampah. Sampah pasar pada umumnya memiliki pengaruh yang besar terhadap lingkungan sekitar pasar. Volume dan jumlah sampah yang ada di tempat pembuangan sampah pada pasar tradisional sangat besar. Dari study literatur yang dilakukan peneliti, ada beberapa poin penting yang patut diperhatikan dalam pengelolaan masalah sampah pasar tradisional. Yang pertama adalah pengangkutan sampah dilakukan $2 \mathrm{x}$ dalam sehari untuk selanjutnya dibuang ke pembuangan sampah akhir dan tidak ada tindak lanjut dari pengangkutan sampah tersebut. Kepentingan masyarakat tersebut bisa

menjadi pertimbangan untuk meningkatkan skala prioritas dalam pengelolaan sampah karena dengan pengelolaan sampah yang sebatas mengangkut sampah $2 \mathrm{x}$ sehari tidak cukup karena sampah menumpuk dan menimbulkan bau tidak sedap. Selain itu, adanya pemandangan yang tidak menyenangkan karena sampah tidak ada pemisahan antara sampah kering dan sampah basah.

\section{b. Dampak Ekonomi}

Dampak ekonomi dalam pembahasan ini meliputi dampak relokasi pasar terhadap pendapatan pedagang dan akses ekonomi masyarakat yang tinggal di sekitar pasar sementara Jl. Cipto Mangunkusumo. Dampak adalah perubahan lingkungan oleh suatu kegiatan (Sudarmo, 1996, h.87). Lingkungan yang dimaksud dalam hal ini bisa berupa lingkungan fisik dan non fisik, lingkungan fisik adalah lingkungan yang meliputi aspek fisik yaitu lahan atau alam sedangkan lingkungan non fisik adalah lingkungan yang tidak bersifat fisik yaitu lingkungan sosial-budaya, ekonomi, dll. sehingga dampak ekonomi dalam pembahasan ini adalah perubahan lingkungan ekonomi yang terjadi oleh suatu kegiatan yaitu relokasi Pasar Songgolangit ke Pasar Penampungan Sementara Jl. Cipto Mangunkusumo. 
Dari hasil study literatur Nisa'Un (2019) peneliti, umumnya para pedagang tidak mengalami penurunan pendapatan karena minimnya pembeli walaupun ada sebagian pedagang yang merasakan pendapatannya turun. Para pedagang yang merasa pendapatannya berkurang hanya mencakup sebagian kecil saja sedangkan sebagian besar pedagang di Pasar Jl. Cipto Mangunkusumo tidak mengalami penurunan dan cenderung stabil dan bahkan banyak pedagang yang mengaku pendapatan mereka meningkat setelah pasar direlokasi. Relokasi ke Jl. Cipto Mangunkusumo bagi mayoritas pedagang dapat dianggap sebagai dampak ekonomi yang positif. Peningkatan dan penurunan pendapatan yang dialami pedagang di Jl. Cipto Mangunkusumo disebabkan oleh jumlah pembeli. Tata letak pedagang di Jl. Cipto Mangunkusumo memang sedikit berbeda dengan di Pasar Songgolangit dulu sehingga sehingga berpengaruh terhadap akses pembeli kepada pedagang. Pedagang yang mendapat kios dan pedagang kaki lima yang dekat area parkir merasakan peningkatan pendapatan karena mudahnya akses pembeli ke pedagang tersebut. Berbeda dengan pedagang yang tempat berjualannya masuk lebih jauh ke dalam pasar, para pedagang ini mengalami penurunan pendapatan karena banyak pembeli yang malas untuk berjalan jauh ke dalam untuk membeli barang di pasar.

Selanjutnya mengenai akses ekonomi masyarakat, hasil study literatur Nisa'Un (2019) peneliti menunjukkan bahwa proses relokasi ke pasar Jl. Cipto Mangunkusumo telah membuka lapangan kerja baru bagi masyarakat sekitar Jl. Cipto Mangunkusumo. Terbukanya lapangan kerja baru ini yang di sebut sebagai akses ekonomi masyarakat Jl. Cipto Mangunkusumo. Banyak warga Keniten yang memilih berusaha atau berdagang di Pasar Jl. Cipto Mangunkusumo ada yang bekerja sebagai juru parkir, pedagang kaki lima, maupun pedagang yang menyewa kios atau bedak. Sumodiningrat (2011, h.7) menjelaskan bahwa dalam rangka membangun kekuatan ekonomi masyarakat dibutuhkan dukungan pemerintah dalam bentuk memperkuat posisi kemitraan usaha ekonomi masyarakat yang dalam kasus relokasi ke Pasar Jl. Cipto Mangunkusumo ini, terbukanya akses ekonomi bagi masyarakat Jl. Cipto Mangunkusumo dapat menjadi salah satu upaya dalam mencapai kemandirian ekonomi masyarakat walaupun masih dalam skala usaha kecil. 


\section{KESIMPULAN}

1. Relokasi pasar akibat revitalisasi pembangunan Pasar Songgolangit, menurut teori Losch, sudah tepat karena terletak pada ruang lingkup perkotaan. Selain itu, penentuan lokasi pasar baru ini juga mempertimbangakan permintaan konsumen yang menunjukkan keterjangkauan konsumen dalam membeli kebutuhan pokok.

2. Dampak Relokasi Pasar Songgolangit Pada Bidang Sosial tidak berdampak signifikan terdapat perubahan pelanggan tetap tetapi diiringi dengan terdapat pelanggan baru, pada dampak kemacetan dan pembuangan sampah sudah cukup baik dalam pengelolaa.

3. Dampak Relokasi Pasar Songgolangit Pada Bidang Ekonomi berdampak pada peningkatan dan penurunan pendapatan hal ini disebabkan oleh perubahnyapembeli dan tata letak lokasi pedang yang berbda dari sebelumnya. Pada relokasi Pasar songgolangit juga berdampak pada dibukanya lapangan kerja baru ditinjau dari ramainya toko-toko disekitar Pasar Jl. Cipto Mangunkusumo yang dibuka kembali yang dulu sempat tutup akibat relokasi RS Harjono.

\section{DAFTAR PUSTAKA}

Djojodipuro, Marsudi, (1992), Teori Lokasi. Fakultas Ilmu Ekonom Universitas Indonesia, Jakarta

NISA' UN LU'LU' (2019). Analisis Persepsi Pedagang dan Kebijakan Pemerintah Terhadap Relokasi Pasar Songgolangit Kabupaten Ponorogo.

Miles, M. E. (1999). Real Estate Development, Principles and Process. Washington D.C: Urban Land Institue

Sjafrizal, 2008. "Teori Lokasi Pasar". Balikpapan : Dinas Pasar Balik Papan

Sumodiningrat, Gunawan. Membangun Perekonomian Rakyat, (Yogyakarta: Pustaka Pelajar 1998)

Wijaya, mahendra.2007. Perspektif Sosiologi Ekonomi dari Masyarakat Prakapitalis Hingga Kapitalisme Neo-liberal. Surakarta: Lindu Pustaka 